\title{
Vaccination rates in a multicultural population
}

\author{
M F van der Wal, A C M Diepenmaat, J M Pel, R A Hirasing
}

Arch Dis Child 2005;90:36-40. doi: 10.1136/adc.2003.047126

See end of article for authors' affiliations

.....................

Correspondence to: Dr M F van der Wal, Municipal Health Service,

Amsterdam, Department of Epidemiology, Documentation and Health Promotion, PO Box 2200, 1000 CE Amsterdam, Netherlands; mvdwal@ gggd.amsterdam.nl

Accepted 4 May 2004

\begin{abstract}
Aims: To establish whether there are social or cultural groups of children in Amsterdam with relatively low vaccination coverage for diphtheria, pertussis, tetanus, and poliomyelitis (DPTP), and for measles, mumps, and rubella (MMR).

Methods: All of the 57382 children aged between 5 and 12 years and living in Amsterdam on 1 January 2003 were analysed with respect to vaccination and sociodemographic data collected routinely by the Department of Child Health Care. The State Vaccination Programme (SVP) guidelines were adhered to in order to determine vaccination status.

Results: The overall respective DPTP and MMR vaccination rates were $93.0 \%$ and $93.9 \%$. No great differences in vaccination levels were found between depressed and affluent areas or between the children of Dutch and non-Dutch mothers. However, foreign children who had been born abroad (Surinam, Morocco, Turkey) were most likely not to have been fully vaccinated. Children who attended anthroposophical schools were also found to be considerably less frequently fully immunised than those at other types of schools.

Conclusions: Vaccination coverage for children domiciled in Amsterdam was very high. Nevertheless, there are groups where the vaccination level is relatively low and social contact is high.
\end{abstract}

$\mathrm{S}$ ince 1952 the State Vaccination Programme (SVP) has taken responsibility for the vaccination of children in the Netherlands. Participation in the SVP is voluntary and free of charge, and there is no school admission immunisation law. The vaccination programme is carried out by local immunisation organisations and by child health clinics. The doctors and nurses employed at these clinics are responsible for the vaccinating of children. They also check the vaccination data of each child who visits the clinic for periodical health check-ups and they recommend immunisation for those who have not been vaccinated. The immunisation organisations call up the children for their various vaccinations and are also responsible for the administrative processing of all the information. Children who are not taken to the child health clinics can be vaccinated by their general practitioner or, in case of hospitalisation, by their paediatrician. The vaccinating of such children is also registered by the immunisation organisations.

Since 1962, children living in the Netherlands have been injected with a combination vaccine for diphtheria, pertussis, tetanus, and poliomyelitis (DPTP). The current standard vaccination scheme is as follows: four doses of DPTP vaccine at the ages of 2,3,4, and 11 months, followed by two doses of diphtheria, tetanus, and poliomyelitis (DTP) vaccine at 4 and 9 years of age. Since 1987 the combination vaccine for measles, mumps, and rubella (MMR) has been given to children at 14 months and at 9 years of age. Since 1993, children have also been vaccinated against Haemophilus influenza type b (Hib). The Hib immunisation is given four times in a child's first year and at the same time as the DPTP injections. Since 2003 children have been vaccinated against meningitis $C$ at 14 months when they are also given their first MMR vaccination. Among children in the Netherlands the vaccination rate is very high. For example, in 2002 the vaccination level for 9 year olds was $95.2 \%$ for DPTP and 96.1\% for MMR. ${ }^{1}$ Those who are not vaccinated usually benefit from the group immunity arising from this high vaccination level.

The chance of an infectious disease spreading is greater among groups where the vaccination level is relatively low and social contact is high. This was the reason why, despite the high national vaccination rate, a polio epidemic was witnessed in 1971, 1978, and 1992/93 which arose chiefly among children who had not been vaccinated for religious reasons..$^{2-4}$ In recent decades a new group of objectors has emerged, namely those who have refused vaccination on the grounds of anthroposophic convictions. The measles explosions of 1987/88 and 1992/93 were especially evident among children who had not been vaccinated on religious or anthroposophic grounds. ${ }^{56}$ A third important group of incompletely vaccinated children are those who have migrated from Surinam, Morocco, and Turkey and who are predominantly housed in the older districts of larger cities. Because these children frequently travel to and from the countries of origin they can easily import illnesses that are vaccinated against in the Netherlands. For instance, in 2000 an imported measles outbreak developed in Ireland. The outbreak began in an area of Dublin that has both a large immigrant population and low MMR vaccination coverage $(76 \%){ }^{7}$ In 1993, Chicago (USA) experienced a large urban outbreak of pertussis, predominantly among Hispanic children. ${ }^{8}$

Amsterdam is a community where more than $60 \%$ of the children are the offspring of migrants; it is an area that accommodates a growing group of anthroposophic oriented parents, as well as families with different religions. We set out to establish whether in Amsterdam, in 2003, there are sociodemographic groups of school children with relatively low vaccination levels for DPTP and MMR. We shall not consider Hib because vaccination levels for Hib and DPTP are virtually the same.

\section{METHODS}

The immunisation data and the sociodemographic information that are routinely recorded by the Department of Child

Abbreviations: DPTP, diphtheria, pertussis, tetanus, and poliomyelitis; DTP, diphtheria, tetanus, and poliomyelitis; MMR, measles, mumps, and rubella; SES, socioeconomic status; SVP, State Vaccination Programme 
Table 1 Vaccination level for DPTP and MMR by sociodemographic variables, 1 January 2003

\begin{tabular}{|c|c|c|c|c|c|c|c|}
\hline & \multirow[b]{2}{*}{$\mathbf{n}$} & \multicolumn{3}{|c|}{ DPTP immunisation } & \multicolumn{3}{|c|}{ MMR immunisation } \\
\hline & & $\begin{array}{l}\text { Fully } \\
\%\end{array}$ & $\begin{array}{l}\text { Partly } \\
\%\end{array}$ & $\begin{array}{l}\text { Not } \\
\%\end{array}$ & $\begin{array}{l}\text { Fully } \\
\%\end{array}$ & $\begin{array}{l}\text { Partly } \\
\%\end{array}$ & $\begin{array}{l}\text { Not } \\
\%\end{array}$ \\
\hline \multicolumn{8}{|l|}{ Gender* } \\
\hline Boy & 29227 & 92.9 & 5.4 & 1.7 & 94.0 & 2.3 & 3.7 \\
\hline Girl & 28147 & 93.0 & 5.2 & 1.8 & 93.8 & 2.3 & 3.9 \\
\hline \multicolumn{8}{|l|}{ Age (in years) } \\
\hline $5-8$ & 28997 & 93.0 & 5.1 & 1.9 & 94.8 & 0.0 & 5.2 \\
\hline $9-12$ & 28385 & 92.9 & 5.5 & 1.6 & 93.0 & 4.7 & 2.4 \\
\hline \multicolumn{8}{|c|}{ Mother's; child's country of birth $\dagger$} \\
\hline Netherlands & 23077 & 96.4 & 3.3 & 0.4 & 95.8 & 1.5 & 2.6 \\
\hline Suriname & 6918 & 94.9 & 4.9 & 0.2 & 95.5 & 3.1 & 1.4 \\
\hline Netherlands & 6451 & 95.8 & 4.2 & 0.1 & 96.2 & 2.7 & 1.1 \\
\hline Foreign & 467 & 82.2 & 15.4 & 2.4 & 87.2 & 8.6 & 4.3 \\
\hline Morocco & 8747 & 96.7 & 3.2 & 0.1 & 97.3 & 1.5 & 1.1 \\
\hline Netherlands & 8208 & 97.3 & 2.7 & 0.0 & 97.6 & 1.4 & 1.0 \\
\hline Foreign & 539 & 86.3 & 12.1 & 1.7 & 93.1 & 3.7 & 3.2 \\
\hline Turkey & 5115 & 96.9 & 3.0 & 0.1 & 97.0 & 1.8 & 1.2 \\
\hline Netherlands & 4876 & 97.6 & 2.3 & 0.0 & 97.5 & 1.6 & 0.9 \\
\hline Foreign & 238 & 82.4 & 16.4 & 1.3 & 87.5 & 6.7 & 5.9 \\
\hline Other & 9623 & 93.0 & 6.2 & 0.8 & 94.6 & 2.2 & 3.2 \\
\hline \multicolumn{8}{|c|}{ SES of the neighbourhood $\ddagger$} \\
\hline Very high & 6240 & 93.7 & 4.2 & 2.1 & 94.1 & 1.6 & 4.3 \\
\hline High & 23664 & 93.5 & 4.9 & 1.6 & 94.0 & 2.1 & 3.9 \\
\hline Low & 20477 & 93.6 & 4.9 & 1.5 & 94.5 & 2.3 & 3.2 \\
\hline Very low & 5973 & 89.1 & 8.1 & 2.8 & 92.0 & 3.5 & 4.5 \\
\hline \multicolumn{8}{|l|}{ Type of school§ } \\
\hline State school & 24811 & 95.3 & 4.1 & 0.6 & 95.6 & 2.0 & 2.3 \\
\hline Protestant & 7858 & 96.3 & 3.3 & 0.4 & 96.9 & 1.6 & 1.6 \\
\hline Roman Catholic & 8070 & 96.6 & 3.1 & 0.4 & 96.6 & 1.5 & 1.9 \\
\hline Ecumenical & 2905 & 93.5 & 5.6 & 0.9 & 94.3 & 3.0 & 2.7 \\
\hline Evangelical & 348 & 95.4 & 4.3 & 0.3 & 96.8 & 2.3 & 0.9 \\
\hline Islamic & 1706 & 96.1 & 3.5 & 0.4 & 96.5 & 1.7 & 1.8 \\
\hline Anthroposophic & 353 & 79.6 & 14.7 & 5.7 & 65.4 & 6.5 & 28.0 \\
\hline Other & 4283 & 94.6 & 4.1 & 1.3 & 94.3 & 2.0 & 3.6 \\
\hline $\begin{array}{l}\text { *Gender unknown } \\
\text { †Country of birth o } \\
\text { †Socioeconomic stc } \\
\S \text { Type of school un }\end{array}$ & $\begin{array}{l}\text { case of } \\
\text { wn in th }\end{array}$ & $\begin{array}{l}\text { hildrer } \\
\text { of } 102\end{array}$ & & & & & \\
\hline
\end{tabular}

Health Care within the Municipal Health Service in Amsterdam were analysed. The Department of Child Health Care's client register is based on Amsterdam's municipal population register. Registration in the local population register is obligatory for everyone resident in the Netherlands. Sociodemographic data included gender, year of birth, country of birth of mother and child, name of school, and postal code. On the basis of the Guide to Amsterdam Schools 2002/2003, schools were classified according to their persuasion: public sector, Protestant, Roman Catholic, ecumenical, Evangelical, Islamic, anthroposophic, and others. ${ }^{9}$ On the basis of postal codes, children were classified according to the district in which they lived. The socioeconomic status of the district was estimated according to the percentage of people between 15 and 64 years of age receiving benefit. Those percentages were obtained from the "basic statistics for districts and neighbourhoods" registered by the Central Statistical Office (in Dutch: the CBS) and published on an annual basis. Districts were divided into four socioeconomic categories on the basis of 10th, 50th, and 90th centile scores: very high, high, low, and very low.

We established for all 57382 Amsterdam children between 5 and 12 years of age, born in the 1990-97 period, whether by 1 January 2003 they had been fully vaccinated against DPTP and MMR. For these purposes the SVP guidelines were followed. Information on logistic regression was used to determine multivariate correlations between sociodemographic variables and incomplete vaccination status. Due to the large number of children involved, small differences between sociodemographic groups would be statistically significant. For this reason we call the result statistically significant if $\mathrm{p}<0.01$, and meaningfully different if the odds ratio equals or exceeds 2.00 .

\section{RESULTS}

On 1 January 2003 the average vaccination rate for DPTP was $93.0 \%$, and for MMR it was $93.9 \%$. The vaccination rates in the various districts ranged between $79.0 \%$ and $99.4 \%$ for DPTP and $81.9 \%$ and $98.4 \%$ for MMR. Table 1 shows the percentages of children in the different sociodemographic groups who have been vaccinated against DPTP and MMR fully, partly, or not at all. Interestingly, the vaccination level was practically the same for the children of Dutch mothers as for the children of non-Dutch mothers. The MMR vaccination level for children with a Dutch born mother was, for example, $95.8 \%$. In cases where the mother was born in Surinam, Morocco, or Turkey, the MMR vaccination levels were $95.5 \%$, $97.3 \%$, and $97.0 \%$ respectively. It is furthermore remarkable that with most sociodemographic groups the percentage of children without any vaccination against DPTP was below $2 \%$. In negative terms the high proportion $(28 \%)$ of children attending anthroposophic schools who are not MMR vaccinated is remarkable.

Tables 2 and 3 present the associations between sociodemographic variables and incomplete immunisation status for DPTP and MMR respectively. After correction no significant incomplete immunisation status differences could be found between districts with different socioeconomic statuses. With DPTP and MMR, incomplete immunisation was more common among foreign born Surinamese children than among Dutch children (adjusted odds ratio 6.52 for DPTP and 3.72 for MMR). The same was true of foreign born 
Table 2 Crude and adjusted odds ratios for the association between sociodemographic variables and not being (fully) vaccinated for DPTP

\begin{tabular}{|c|c|c|c|c|c|}
\hline & \multicolumn{5}{|c|}{ Not (fully) vaccinated against DPTP } \\
\hline & $\%$ & ORI* & $99 \% \mathrm{Cl}$ & OR2* & $99 \% \mathrm{Cl}$ \\
\hline \multicolumn{6}{|l|}{ Gender } \\
\hline Boy & 7.1 & 1 & & 1 & \\
\hline Girl & 7.0 & 0.99 & 0.91 to 1.08 & 0.98 & 0.85 to 1.11 \\
\hline \multicolumn{6}{|l|}{ Age (in years) } \\
\hline $5-8$ & 7.0 & 1 & & 1 & \\
\hline $9-12$ & 7.1 & 1.01 & 0.93 to 1.10 & 1.13 & 0.99 to 1.30 \\
\hline \multicolumn{6}{|c|}{ Mother's; child's country of birth } \\
\hline Netherlands & 3.6 & 1 & & 1 & \\
\hline Suriname; Netherlands & 4.2 & 1.17 & 0.97 to 1.40 & 1.30 & 1.04 to 1.64 \\
\hline Suriname; foreign & 17.8 & 5.71 & 4.13 to 1.40 & 6.52 & 4.36 to 9.74 \\
\hline Morocco; Netherlands & 2.7 & 0.72 & 0.59 to 0.88 & 0.90 & 0.71 to 1.14 \\
\hline Morocco; foreign & 13.7 & 4.20 & 3.01 to 5.87 & 4.54 & 3.07 to 6.71 \\
\hline Turkey; Netherlands & 2.4 & 0.64 & 0.49 to 0.83 & 0.75 & 0.55 to 1.01 \\
\hline Turkey; foreign & 17.6 & 5.66 & 3.62 to 8.85 & 6.21 & 3.67 to 10.5 \\
\hline Other & 7.0 & 2.00 & 1.75 to 2.29 & 1.79 & 1.49 to 2.15 \\
\hline \multicolumn{6}{|l|}{ SES of the neighbourhood } \\
\hline Very high & 6.3 & 1 & & 1 & \\
\hline High & 6.5 & 1.03 & 0.89 to 1.20 & 1.13 & 0.88 to 1.46 \\
\hline Low & 6.4 & 1.02 & 0.87 to 1.18 & 1.22 & 0.93 to 1.58 \\
\hline Very low & 10.9 & 1.83 & 1.54 to 2.17 & 1.32 & 0.95 to 1.82 \\
\hline \multicolumn{6}{|l|}{ Type of school } \\
\hline State school & 4.7 & 1 & & 1 & \\
\hline Protestant & 3.7 & 0.76 & 0.64 to 0.91 & 0.82 & 0.66 to 1.01 \\
\hline Roman Catholic & 3.4 & 0.72 & 0.61 to 0.86 & 0.73 & 0.59 to 0.91 \\
\hline Ecumenical & 6.5 & 1.41 & 1.14 to 1.73 & 0.99 & 0.74 to 1.31 \\
\hline Evangelical & 4.6 & 0.97 & 0.50 to 1.88 & 0.63 & 0.26 to 1.53 \\
\hline Islamic & 3.9 & 0.81 & 0.58 to 1.13 & 0.80 & 0.53 to 1.21 \\
\hline Anthroposophic & 20.4 & 5.16 & 3.64 to 7.31 & 8.39 & 5.80 to 12.1 \\
\hline Other & 5.4 & 1.15 & 0.95 to 1.39 & 1.20 & 0.95 to 1.53 \\
\hline
\end{tabular}

Moroccan children (adjusted odds ratio 4.54 for DPTP and 1.48 for MMR) and foreign born Turkish children (adjusted odds ratio 6.21 for DPTP and 3.78 for MMR). Incomplete DPTP vaccination status was clearly higher among children attending anthroposophist schools than among children at state schools (adjusted odds ratio 8.39). This also proved true in the case of MMR (adjusted odds ratio 15.16).

\section{DISCUSSION}

The average vaccination rates established by us for Amsterdam were high and, indeed, above the World Health Organisation norm of $90 \% .{ }^{10}$ In view of the fact that today under-registration, in conjunction with vaccination data, is a minor problem in Amsterdam, the reported rates may be seen as fairly reliable. This is partly due to the fact that since September 2001 all child health care clinics have been receiving monthly overviews indicating which of their children have been fully vaccinated and giving a per child breakdown of the vaccinations still needing to be administered. The child health clinics then compare the vaccination administration details with their own health files on each child and report any details that might be missing.

In Amsterdam, by contrast to what might be said aboutfor instance-the United Kingdom, ${ }^{11}$ we found no large differences between depressed and affluent areas as far as vaccination rates were concerned. It is conceivable that the socioeconomic differences between districts are in fact greater in that country than in the Netherlands. It is also possible that in the United Kingdom the vaccination levels for the children of immigrants (who are predominantly concentrated in depressed areas) are much lower than for indigenous children, even though there are no recent figures. ${ }^{12}$ More recent figures are available for the United States $^{13}$ and Germany, ${ }^{14}$ which show lower vaccination rates among (inner) city minority children. Unlike 20 years ago, the vaccination rate in Amsterdam is not lower for the children of immigrants than for the children of indigenous parents. For example, in 1984 the DPTP vaccination rate for $1-14$ year olds with a Dutch born mother was $77 \%$, while the level among children in a similar age range whose mothers were born in Turkey or Morocco was respectively $41 \%$ and $43 \% .{ }^{15}$ In 2003 this was, in the 5-12 age range, $96.4 \%$ for children with a mother born in the Netherlands as opposed to $96.7 \%$ and $96.9 \%$ respectively for children with Moroccan and Turkish born mothers.

The vaccination level, however, for the children of immigrants who, like their parents, had also been born abroad was lower than for the children of immigrants born in the Netherlands. This corresponds with previous research carried out in the Netherlands. ${ }^{16-18}$ A markedly lower vaccination coverage among foreign born children has also been reported for the USA. ${ }^{19}$ The following factors possibly have a contributory role. Firstly, because of the continual inflow of immigrant children there are always those who are in the process of completing series of vaccinations. It takes at least eight months for a child of immigrants who have settled in the Netherlands to be fully vaccinated. This means that in Amsterdam a vaccination level of $100 \%$ is never attainable. Secondly, children who have moved to the Netherlands at an older age will always have missed out on the intensive intervention surrounding child health care in the first year of a child's life. In that first year much information is issued about vaccinations, both in writing and verbally (and through interpreters where necessary). If the parent and child do not appear at the clinic, the nurse will make a home visit. Older children tend to be less intensively targeted and followed up by the child health care system. Thirdly, it is particularly among the group of children born abroad that 


\begin{tabular}{|c|c|c|c|c|c|}
\hline & \multicolumn{5}{|c|}{ Not (fully) vaccinated against MMR } \\
\hline & $\%$ & OR $1^{*}$ & $99 \% \mathrm{Cl}$ & OR2* & $99 \% \mathrm{Cl}$ \\
\hline \multicolumn{6}{|l|}{ Gender } \\
\hline Boy & 6.0 & 1 & & 1 & \\
\hline Girl & 6.2 & 1.04 & 0.95 to 1.13 & 1.03 & 0.91 to 1.18 \\
\hline \multicolumn{6}{|l|}{ Age (in years) } \\
\hline $5-8$ & 5.2 & 1 & & 1 & \\
\hline $9-12$ & 7.0 & 1.38 & 1.26 to 1.51 & 1.48 & 1.30 to 1.70 \\
\hline \multicolumn{6}{|c|}{ Mother's; child's country of birth } \\
\hline Netherlands & 4.2 & 1 & & 1 & \\
\hline Suriname; Netherlands & 3.8 & 0.92 & 0.77 to 1.11 & 1.05 & 0.84 to 1.31 \\
\hline Suriname; foreign & 12.8 & 3.40 & 2.36 to 4.91 & 3.72 & 2.39 to 5.80 \\
\hline Morocco; Netherlands & 2.4 & 0.57 & 0.46 to 0.70 & 0.73 & 0.57 to 0.92 \\
\hline Morocco; foreign & 6.9 & 1.70 & 1.09 to 2.66 & 1.48 & 0.86 to 2.55 \\
\hline Turkey; Netherlands & 2.5 & 0.59 & 0.46 to 0.76 & 0.69 & 0.52 to 0.92 \\
\hline Turkey; foreign & 12.5 & 3.33 & 2.00 to 5.55 & 3.78 & 2.14 to 6.68 \\
\hline Other & 5.4 & 1.31 & 1.13 to 1.51 & 1.28 & 1.07 to 1.54 \\
\hline \multicolumn{6}{|l|}{ SES of the neighbourhood } \\
\hline Very high & 5.9 & 1 & & 1 & \\
\hline High & 6.0 & 1.01 & 0.86 to 1.18 & 1.16 & 0.92 to 1.46 \\
\hline Low & 5.5 & 0.93 & 0.80 to 1.09 & 1.16 & 0.90 to 1.48 \\
\hline Very low & 8.0 & 1.39 & 1.15 to 1.67 & 1.01 & 0.73 to 1.41 \\
\hline \multicolumn{6}{|l|}{ Type of school } \\
\hline State school & 4.4 & 1 & & 1 & \\
\hline Protestant & 3.1 & 0.71 & 0.58 to 0.85 & 0.74 & 0.60 to 0.91 \\
\hline Roman Catholic & 3.4 & 0.77 & 0.65 to 0.92 & 0.79 & 0.65 to 0.97 \\
\hline Ecumenical & 5.7 & 1.32 & 1.06 to 1.65 & 1.07 & 0.80 to 1.43 \\
\hline Evangelical & 3.2 & 0.72 & 0.32 to 1.58 & 0.59 & 0.22 to 1.60 \\
\hline Islamic & 3.5 & 0.80 & 0.57 to 1.13 & 0.97 & 0.65 to 1.45 \\
\hline Anthroposophic & 34.6 & 11.59 & 8.60 to 15.6 & 15.16 & 11.1 to 20.8 \\
\hline Other & 5.7 & 1.31 & 1.09 to 1.59 & 1.25 & 1.00 to 1.56 \\
\hline
\end{tabular}

OR1 = crude odds ratio; OR2 = adjusted odds ratio.

*Significant and meaningful differences are emboldened

the chance of vaccination data being under-registered is greatest. Sometimes parents claim that their child has been sufficiently vaccinated abroad, but they are unable to produce the relevant paperwork. If the vaccination papers cannot be produced, the child has to be vaccinated again according to SVP directives. If, however, the vaccination papers are available, the vaccination data has to be sent to the relevant local immunisation organisation. It is possible that both the vaccinating "anew" and the submitting of the relevant data are not systematically carried out. Finally, children who have moved to the Netherlands from elsewhere will often be vaccinated according to an adapted programme that will depend on the age of the child and the vaccinations received in the country of origin. Previous research has shown that the knowledge that doctors and nurses possessed of alternative vaccination schemes was sometimes inadequate. ${ }^{20}$

The vaccination level for children born abroad, however, is increasing. In 1999, for instance, $24.7 \%$ of the $2-12$ year olds born in Morocco turned out to be insufficiently protected against DPTP compared to $14.9 \%$ for 5-12 year olds in 2003 . For MMR the comparable figures were $13.3 \%$ and $6.9 \%$ respectively. ${ }^{16}$ There are at least two activities that have possibly contributed to the improved vaccination rate of Amsterdam children born abroad. Firstly, over the past 10 years doctors and nurses at the child health clinics are periodically trained and tested on alternative vaccination schemes. Secondly, in the past four years the clinics have been instructed to commence their vaccination programme immediately whenever children come from abroad. Each month the clinics receive overviews concerning children for whom, six months after having settled in Amsterdam, the vaccination administration authorities know no vaccination details. A previous study in Georgia (USA) showed that regular assessment and vaccination data feedback could stimulate public clinics to improve their vaccination coverage. $^{21}$

There are various groups who refuse vaccination on religious or lifestyle grounds, such as anthroposophics, microbiologists, and Christian Science believers. ${ }^{22}$ On the whole, the children of such parents tend to be protected by group immunity because they are not restricted to sociogeographical groups, with the exception of the anthroposophics whose children attend special anthroposophic schools. The DPTP and MMR vaccination rate for children in the anthroposophist education system was $79.6 \%$ and $65.4 \%$ respectively, compared with $95.3 \%$ and $95.6 \%$ for children in general primary schools. As soon as vaccination rates drop, the positive effect of group immunity rapidly disappears, so that the chance of children getting one or other of the illnesses considerably increases. ${ }^{23}$ A certain percentage of parents who are sceptical about injecting can be persuaded to have their children vaccinated once they have been informed of the (putative) side effects. A study conducted in the Netherlands showed that four of the five indigenous parents who had refused the MMR injection were dissatisfied with the routine information that had been issued. ${ }^{24}$ One thing that has made it more important for particular attention to be devoted to parents who are hesitant about having their children vaccinated is the fact that in Amsterdam in the past five years, two private child health clinics have opened up that are run along anthroposophical lines. The vaccination rates for 2-4 year olds who fell under the responsibility of those clinics (201 children) was, on 1 January 2003, 44.3\% for DPTP and 22.4\% for MMR (results not presented).

In various countries where vaccination rates are high, as in the Netherlands, it is becoming increasingly difficult to retain this high rate because of increasing reservations about 
vaccinating, on the part of both parents and experts. ${ }^{25}$ Signs of increasing reluctance to vaccinate are not (yet) detectable in Amsterdam. For instance, the proven negative side effects of the DPTP and MMR vaccines derive predominantly from the pertussis and measles components. In 1984, 4\% of Amsterdam children born in 1982 had, at the parents' request, been given a combination vaccine for diphtheria, tetanus, and poliomyelitis (DTP) instead of the standard DPTP vaccination. ${ }^{15}$ By 2003, however, the percentage for the birth year 2001 had fallen to $1 \%$ (results not presented).

To conclude, the vaccination level in Amsterdam may be termed very high. Nevertheless, there are groups where the vaccination level is relatively low and the social contact high. If their vaccination levels are to be improved, these groups must be given sustained attention.

\section{Authors' affiliations \\ M F van der Wal, A C M Diepenmaat, Municipal Health Service,} Amsterdam, Department of Epidemiology, Documentation and Health Promotion, Amsterdam, Netherlands

J M Pel, Municipal Health Service, Amsterdam, Department of Child Health Care, Provincial Immunisation Administration, Amsterdam, Netherlands

R A Hirasing, Municipal Health Service, Amsterdam, Department of Child Health Care, Free University, Amsterdam, Department of Social Medicine, Institute for Research in Extramural Medicine, Amsterdam, Netherlands

\section{REFERENCES}

Anon. Vaccinatietoestand Nederland per 1 januari 2002. Den Haag: Ministerie van Vollksgezondheid, Welzijn en Sport, 2003

2 Bijkerk H, Draaisma FJ, Landheer T, et al. Poliomyelitisepidemie in Staphorst Ned Tijdschr Geneeskd 1972;1 16:549-58.

3 Bijkerk H, Draaisma FJ, Van der Gugten AC, et al. De poliomyelitis-epidemie in 1978. Ned Tiidschr Geneeskd 1979;123:1700-14.

4 Oostvogel PM, Van Wijngaarden JK, Van der Avoort HGAM, et al. Poliomyelitis outbreak in an unvaccinated community in the Netherlands, 1992-93. Lancet 1994;344:665-70.

5 Bijkerk H, Bilkert-Mooiman MAJ, Houtters HJ. De inentingstoestand bii aangegeven patiënten met mazelen tijdens de epidemie 1987/'88. Ned Tijdschr Geneeskd 1989;133:29-32.

6 Van 't Spijker C, Rümke HC. Beschermt een gewijzigd vaccinatieschema beter tegen mazelen? Ned Tijdschr Geneeeskd 1994;138:2400-5.
7 Coughlan S, Connell J, Cohen B, et al. Suboptimal measles-mumps-rubella vaccination coverage facilitates an imported measles outbreak in Ireland. Clin Infect Dis 2002;35:84-6

8 Kenyon TA, Izurieta H, Shulman ST, et al. Large outbreak of pertussis among young children in Chicago, 1993: investigation of potential contributing factors and estimation of vaccine effectiveness. Pediatr Infect Dis $J$ 1996; 15:655-61

9 Buro Servicetaken Onderwijs (BSO). Amsterdamse scholengids 2002/2003. Amsterdam: BSO, 2002.

10 World Health Organisation (WHO). Targets for health for all. Copenghagen: WHO, 1985

11 Majeed FA, Chaturvedi N, Reading R, et al. Equity in the NHS. Monitoring and promoting equity in primary and secondary care. $B M$ 1994;308:1426-9.

12 Baker MR, Bandaranayake R, Schweiger MS. Differences in rate of uptake of immunisation among ethnic groups. BMJ (Clin Res Ed) 1984;288:1075-8.

13 Kenyon TA, Matuck MA, Stroh G. Persistent low immunization coverage among inner-city preschool children despite access to free vaccine. Pediatrics 1998;101:612-16.

14 Markuzzi A, Schlipköter U, Weitkunat R, et al. Masern-, mumps- und rötelnimpfstatus bei Münchner schulanfängern. Sozial- und Präventivmedizin 1997:42:133-43.

15 Pauw-Plomp H, Van Wieringen JCM. Vaccinatietoestand van Amsterdamse kinderen. Amsterdam: GG\&GD, 1985.

16 Van der Wal MF, Diepenmaat ACM, Pauw-Plomp H, et al. Hoge vaccinatiegraad van Amsterdamse kinderen. Ned Tijdschr Geneeskd 2001;145:131-5.

17 Brouwer CPE. Onderzoek naar de vaccinatiegraad bij kinderen van groep 2 en groep 8 van de basisscholen in de gemeente Hilversum, en het effect van verwijzing van onvoldoende gevaccineerden bij het periodiek geneeskundig onderzoek. Leiden: TNO-PG, 1994

18 Kuiper CM, Schlesinger-Was EA, Vaandrager GJ. Preventieve gezondheidszorg voor kinderen van migranten: een onderzoek naar de deelname aan de jeugdgezondheidszorg (0-4 jaar) in Den Haag. Tijdschrift voor Sociale Gezondheidszorg 1986;64:365-9.

19 Strine TW, Barker LE, Mokdad AH, et al. Vaccination coverage of foreignborn children 19 to 35 months of age: findings from the National Immunization Survey, 1999-2000. Pediatrics 2002;110:e15.

20 Diepenmaat ACM, Pauw-Plomp H. De Amsterdamse vaccinatietoestand nader bekeken. Amsterdam: GG\&GD, 1995.

21 LeBaron CW, Chaney M, Baughman AL, et al. Impact of measurement and feedback on vaccination coverage in public clinics, 1988-1994. JAMA 1997;277:631-5

22 Van Dijk P. Geneeswiizen in Nederland: compendium van alternatieve geneeswijzen. Deventer: Ankh-Hermes, 1993.

23 Scherer A, McLean A. Mathematical models of vaccination. Br Med Bull 2002;62:187-99

24 Hardon AP, Streefland PH, Egers EM, et al. Acceptatie van vaccinatie onder allochtonen in Amsterdam en Arnhem: een verkennend onderzoek. Amsterdam: Universiteit van Amsterdam, 1998.

25 Gangarosa EJ, Galazka AM, Wolfe CR, et al. Impact of anti-vaccine movements on pertussis control: the untold story. Lancet 1998;351:356-61. 